\title{
sciendo
}

Folia Oeconomica Stetinensia

Volume 21 (2021) Issue 1

DOI: $10.2478 /$ foli-2021-0010
WYDZIAL NAUK EKONOMICZNYCH I ZARZĄDZANIA

\section{THE IMPACT OF FAMILY AND CHILD-ALLOWANCES \\ ON INCOME INEQUALITY IN POLAND. GINI DECOMPOSITION BY INCOME SOURCES}

\author{
Ewa Wędrowska, Ph.D. Associate Professor ${ }^{1}$ \\ Joanna Muszyńska, Ph.D. ${ }^{2}$ \\ Nicolaus Copernicus University \\ Faculty of Economic Sciences and Management \\ Gagarina 13a, 87-100 Toruń, Poland \\ ${ }^{1}$ Department of Economic Applications of Informatics and Mathematics \\ e-mail: Ewa.Wedrowska@umk.pl \\ ORCID: 0000-0003-3902-0896 \\ ${ }^{2}$ Department of Econometrics and Statistics \\ e-mail: Joanna.Muszynska@umk.pl \\ ORCID: 0000-0002-9436-4336
}

Received 12 June 2020, Accepted 10 March 2021

\begin{abstract}
Research background: This paper analyses how different income sources affect the level of inequality in Poland, with focus on the role of family and children related allowances in decreasing income inequalities in 2015-2017. Therefore, the study has focused on the various subgroups of households with children.

Purpose: The paper is aimed at examining the extent to which family and children related allowances affect household income inequality and identifying whether they affect inequality in various groups of households in the same way.

Methodology: The study was carried out on micro-data gathered by Eurostat. To examine the extent to which different income components affect income inequality, we decompose the Gini coefficient according to the method introduced by Lerman and Yitzhaki.

Results: Our study revealed that for most households with children, the inequality-reducing effect due to family and children related allowances increased in 2017 compared to 2015 . However, despite the additional child-raising benefit under the "Family 500+" programme, income taxes and social security contributions remained by far the most important factor in reducing household income inequalities in Poland.

Novelty: To our knowledge, no study has yet attempted to assess the extent to which family and childallowances affect income inequality based on real data. The present analysis takes a step towards filling this gap. Unlike other studies based on microsimulation, in this paper we made use of the representative microdata derived from the EU-SILC study.
\end{abstract}


Keywords: household income, income inequality, Gini coefficient, income source decomposition, EU-SILC

JEL classification: D31, D33, D63

\section{Introduction}

Social protection is necessary in preventing and reducing poverty for children and families, in addressing inequalities and in realizing children's rights (ILO, 2015). Social protection covers the range of policies and programmes targeted at families with children that are part of family policies. Family policies are a relatively late addition to social policies, and they have been developed mainly within Europe (Saraceno, 2011). Nieuwenhuis and Van Lancker (2017) mention the main goals of family policies: poverty reduction and income maintenance, direct compensation for the financial cost of raising children, fostering employment, improving gender equity, support for early childhood development and raising birth rates.

The consequences of poverty and inequality are very significant for children. Children experience poverty differently from adults; they have specific and different needs (UNICEF, 2012). Therefore, child and family benefits play a particularly important role in realizing children's rights and addressing their needs, particularly for the most vulnerable members of society (ILO, 2015). Income security for children is impossible to provide in isolation from the family and household context. Cash benefits for children therefore mirrors the income security of their parents, grandparents or other carers. In this paper, we focus on family and children related allowances for different types of households with children.

Family support, gender roles, and childcare have moved to the centre of recent social reform (Hemerijck, 2012). The manifestations of such initiative are also noticeable in Poland; in 2016 a government programme "Family 500+" was introduced. ${ }^{1}$ The "Family 500+" programme has been the government's attempt to improve the situation of Polish families and to encourage them to have more children (Radzik, 2017). The child-raising benefit of PLN 500 monthly was granted for every second child under 18 and for the first child if the family income was below PLN 800 per capita per month (PLN 1,200 in the case of child disability). Broad eligibility criteria allowed all types of households to apply for benefits (married couples, cohabiting parents, single parents, foster families, etc.). The total cost of the "Family 500+" programme

\footnotetext{
1 The law was adopted in February 2016 and the "Family 500+" programme came into force on 1st April 2016.
} 
is officially estimated at PLN 16 billion in 2016 (April-December) and over PLN 23 billion in 2017 (GUS, 2018). According to Ministry of Family, Labour and Social Policy, in 2015, public spending on family benefits was $1.75 \%$ of GDP and it increased to $3.14 \%$ in 2017 . In 2017, the "Family 500+" programme covered 3.85 million children in 2.5 million families. In Poland, until 2015, family policies concentrated on reducing poverty with income-tested family benefits as the main policy instrument. Income support to all families was also provided in the form of child tax credits, payments of social security contributions for caregivers and price reductions for large families (European Commission, 2016). In this context it would be interesting to know how policy changes which happened in 2016 affected the situation of households with children. Therefore, the aim of this paper is an investigation of how family and children related allowances affect the level of inequality in Poland, with a focus on the various subgroups of households with children in 2015-2017. To achieve this aim, the Gini coefficient decomposition analysis, according to the type of households was carried out. To our knowledge, no study has yet attempted to assess the extent to which family and child-allowances affect income inequality based on real data. The present analysis takes a step towards filling this gap. Unlike other studies based on microsimulation, in this paper we made use of the representative micro-data derived from the European Union Statistics on Income and Living Conditions (EU-SILC).

The introduction of the "Family 500+" programme has provoked intense debate among policymakers and researchers on the directions and goals of family policies, as well as on the desired and undesired impacts of the programme. The programme was implemented in conditions of low fertility rate and depopulation in Poland, and it was introduced mainly to improve the demographic situation. The program may have had a slight impact on the increase in the fertility rate in the first years following its implementation. As argued in the ex-ante analysis by Myck (2016) and ex-post analysis by Magda, Kiełczewska and Brandt (2018), these positive demographic changes came at the cost of reduced female labour market participation. Myck and Trzciński (2019) showed that this reduction primarily affected women with both lower levels of education and living outside of large urban areas. Golinowska and Sowa-Kofta (2017) demonstrated that the 500+ benefit scheme succeeded in reducing income poverty in many families, improving the structure of consumption, but, at the same time, increased the tendency of mothers to leave the labour market. Child and family benefits are usually criticized as contributing to reducing the willingness to work, especially among women. Magda et al. (2018) suggested that the labour market participation rates of women with children decreased after the introduction of the "Family 500+" programme compared to childless women. The influence 
of the "Family 500+" programme on the female labour market was studied also by RuzikSierdzińska (2017), Radzik (2017) and Kmieć (2019).

Some of the studies present evidence on the impact of the "Family 500+" programme to poverty and income inequality reduction. Brzeziński and Najsztub (2017) used the microsimulation approach to estimate the short-term impact of the "Family 500+" programme on household incomes, poverty and income inequality. Their results suggest that the programme will have the strongest impact on the incomes of households at the lower end of income distribution and it can lead to a lower risk of extreme poverty for households with children as compared to small households. Their results are in accordance with those of Szarfenberg (2017), who showed that initial simulations of the program's effect on extreme poverty among children were very promising.

\section{Methodology}

To empirically verify the aim of the study, we employed the Gini coefficient, which is the most popular representative of the family of inequality measures termed as the extended Gini² $^{2}$ (EG). Similarly, to the Atkinson family of indices and Generalized Entropy measures EG covers inequality measures that reflect different social preferences (Yitzhaki, Schechtman, 2005, p. 402). The EG index can be expressed as a covariance between the variable and a power function of its cumulative distribution:

$$
\mathrm{EG}(Y, v)=\operatorname{vCOv}\left(Y,-[1-F(Y)]^{v-1}\right)
$$

where $F(Y)$ is the cumulative distribution. ${ }^{3}$ The EG depends on a parameter $v$, that reflects a relative preference for equality. The standard Gini coefficient corresponds to $v=2$. Higher values put more relative weight on inequality at the bottom part of the distribution, whereas the value $v<2$, places more weight on the top part of the distribution. The higher the value for $v$, the larger the weight placed on poorer households or individuals (Wodon, Yitzhaki, 2002, p.90).

To assess the impact of income components on total income inequality, we decompose the Gini coefficient according to the method proposed by Lerman and Yitzhaki (1985). In the study, we consider a population of $n$ households denoted by $i$, with mean income $\bar{y}$ and assume that the

\footnotetext{
2 In the mathematically oriented literature, the extended Gini is also referred as the S-Gini.

3 The reason for use of $-[1-F(Y)]$ instead of $F(Y)$ in the formula (1) is that the index is required to imitate the social welfare function, which is increasing and concave. In pure statistical use, one may prefer the alternative extension (see Yitzhaki, Schechtman, 2005).
} 
household income consists of $K$ income components. The income from the source $k=(1, \ldots, K)$ for the household $i$ equals $Y_{i k}$. The distribution of incomes from source $k$ is $Y_{k}=\left(Y_{1 k}, Y_{2 k}, \ldots, Y_{n k}\right)$, the distribution of total incomes is $Y=\left(Y_{1}, Y_{2}, \ldots, Y_{n}\right)$, where the total income for the household $i$ equals $Y_{i}=\sum_{k} Y_{i k}$. The cumulative distribution of total income and the cumulative distribution of component $k$ are denoted $F(Y), F\left(Y_{k}\right)$, respectively.

The Gini coefficient is the EG index for $v=2$, normalized by mean income:

$$
\mathrm{G}=2 \operatorname{COV}(Y,-[1-F(Y)]) / \bar{y}
$$

According to Lerman and Yitzhaki (1985), the Gini coefficient for total income inequality, can be decomposed as:

$$
G=\sum_{k=1}^{K} s_{k} G_{k} R_{k}
$$

where: $s_{k}$ presents the share of source $k$ in total income $\left(s_{k}=\bar{y}_{k} / \bar{y}\right) ; G_{k}$ is the Gini coefficient of income source $k ; R_{k}$ is the Gini correlation between income source $k$ and total income.

The Gini correlation is a form of rank correlation coefficient and is defined as the ratio of covariances:

$$
R_{k}=\operatorname{cov}\left(Y_{k} ; F(Y)\right) / \operatorname{cov}\left(Y_{k} ; F\left(Y_{k}\right)\right)
$$

It measures the extent to which the relationship between $Y_{k}$ and the cumulative rank distribution of $Y$ coincides with the relationship between $Y_{k}$ and its own cumulative rank distribution $F_{k}$. The Gini correlation $R_{k}$ can take values between -1 and $1 . R_{k}=0$ if a particular component $Y_{k}$ and $Y$ are independent, and it is equal to $1(-1)$ if $Y_{k}$ is the increasing (decreasing) function of $Y$ (Yitzhaki, Schechtman, 2013, p. 40).

Based on the equation (3), the impact of any income source upon total inequality can be evaluated. The absolute contribution of each income source $k$ to total inequality, $C_{k}$, is the product of the share of that source in total income, $s_{k}$, the Gini coefficient of that income source, $G_{k}$, and its Gini correlation, $R_{k}$ :

$$
C_{k}=s_{k} G_{k} R_{k}
$$

while the relative contribution of each income source to total inequality is the ratio between $C_{k}$ and Gini: $c_{k}=C_{k} / G$. 


\section{Data}

The study is part of the project entitled "Income and inequality of income of European households" (RPP 162/2018-EU-SILC) and was conducted on data gathered by Eurostat (EU-SILC cross-sectional UDB 2016, 2018 - version 2019-09). The micro-data used in the analysis covers information about incomes achieved by individual members of Polish households. In 2016, the sample consisted of 32,609 persons in 11,982 households, while in 2018 the sample included 33,922 persons in 15,214 households. In order to obtain results that correspond to an extrapolation of the measures to the whole population, we used the personal cross-sectional weights during the calculations.

Because for the vast majority of countries, including Poland, the EU-SILC income reference period is a previous year, the data taken from 2016 and 2018 surveys refer to information on income from years 2015 and 2017, respectively. Year 2017 was the first full year when households received social benefits under the "Family look at to" programme, while 2015 was the last year when these benefits were not granted.

In the study, we have examined total household disposable income defined as the sum of gross personal income components for all household members and gross income components at household level, diminished by taxes and social insurance contributions. When analysing the influence of income components on income inequality, we grouped income sources into seven factors. Three of them described market income. These were earnings (labelled as earnings), self-employment income (abbreviated to selfemp) and combined together into one group, and denoted as a residual category of market income (abbreviated to othermarinc), incomes from rental of a property or land, interests, dividends, profit from capital investments.

The other four factors were formed of old-age and survivor's benefits (abbreviated to oldsurv), family and children related allowances (abbreviated to famchild), residual category of social transfers (abbreviated to othersocial) and taxes (labelled as taxes).

The factor describing family and children related allowances were made up of permanent and temporary family allowances, monthly parental benefit for young parents not in employment and child-raising benefit from the "Family 500+" programme.

The group of income defined as residual category of social transfers consisted of unemployment, sickness and disability benefits, education-related allowances, housing allowances as well as social exclusion benefits, not classified elsewhere.

The factor denoted as taxes covered taxes on wealth, inter-household cash transfer paid and tax on income and social insurance contributions. It should be stressed that on the basis 
of EU-SILC data, income taxes cannot be separated from social security contributions (Alves, 2012, p. 42). It also should be noted that taxes form a negative part of disposable income for that reason the share of market income and social transfers in total disposable income accounts for over $100 \%$.

In our analysis, household acts as a unit of the study. Therefore, to take into account differences in household size, all income components were adjusted using the equivalence scales. We applied the OECD-modified equivalence scale that assigns a value of 1 to the household head, of 0.5 to each additional adult member and of 0.3 to each child.

The study was conducted for all households combined together, as well as for groups of households distinguished based on the composition of the household, i.e., the number of adults and dependent children. We analysed the incomes of all types of households, but our particular attention was paid to households having dependent children. Therefore, we have focused on the following subgroups of household:

- single parent with dependent children,

- two adults with one dependent child,

- two adults with two dependent children,

- two adults with three or more dependent children

- and other households with dependent children.

\section{Empirical results}

In the first section, before presenting the results of the decomposition analysis for the distinguished groups, we briefly discuss the income structure and level of income inequality of all Polish households.

In the group of all households, the structure of household income was relatively stable over time (Table 1). As expected, earnings were by far the main source of household disposable income, comprising over $80 \%$ of the total household's income. In both years, the next important components of income were old age and the survivor's benefits as well as selfemployment income. The other components of market income had an exceedingly small share in the disposable income of Poles households (less than 2\%). In 2017, the share of family and children related allowances increased almost three times compared to 2015 . The share of these transfers accounted for less than $2 \%$ of household disposable income in 2015 and $5.6 \%$ in 2017. The shares of residual categories of social transfers in total income remained at a similar level over the period of 2015-2017. 
Table 1. Gini decomposition by factor components for all Polish households

\begin{tabular}{|c|c|c|c|c|c|c|c|c|}
\hline \multirow[t]{2}{*}{ Variable } & \multicolumn{2}{|c|}{$\begin{array}{c}\text { Factor shares } \\
\text { in disposable household } \\
\text { income }(\%)\end{array}$} & \multicolumn{2}{|c|}{$\begin{array}{c}\text { Gini } \\
\text { coefficient }\end{array}$} & \multicolumn{2}{|c|}{$\begin{array}{c}\text { Gini } \\
\text { correlation }\end{array}$} & \multicolumn{2}{|c|}{$\begin{array}{c}\text { Relative contribution } \\
\text { to overall inequality } \\
(\%)\end{array}$} \\
\hline & 2015 & 2017 & 2015 & 2017 & 2015 & 2017 & 2015 & 2017 \\
\hline Earnings & 83.3 & 81.7 & 0.5217 & 0.5136 & 0.7619 & 0.7789 & 111.2 & 117.4 \\
\hline Selfemp & 12.9 & 12.8 & 0.8710 & 0.8744 & 0.2649 & 0.2555 & 10.0 & 10.3 \\
\hline Othermarinc & 1.8 & 1.4 & 0.9562 & 0.9558 & 0.4129 & 0.3429 & 2.4 & 1.6 \\
\hline Oldsurv & 24.6 & 23.8 & 0.7332 & 0.7207 & 0.1824 & 0.1162 & 11.0 & 7.2 \\
\hline Famchild & 1.9 & 5.6 & 0.9060 & 0.7794 & -0.0909 & -0.1151 & -0.5 & -1.8 \\
\hline Othersocial & 3.8 & 3.2 & 0.8770 & 0.8886 & -0.1831 & -0.2335 & -2.0 & -2.4 \\
\hline Taxes & -28.3 & -28.4 & -0.4010 & -0.3863 & -0.8412 & -0.8179 & -32.0 & -32.3 \\
\hline Total & 100.0 & 100.0 & 0.2978 & 0.2784 & 1.0000 & 1.0000 & 100.0 & 100.0 \\
\hline
\end{tabular}

Source: authors' own calculations.

We find that household disposable income inequality is much lower than the inequality in income components (Table 1). Over the period of 2015-2017, the Gini coefficient of household disposable income decreased from 0.298 to 0.278 . Earnings have contributed most to income inequality, which reveals some similarity to their dominant share in total household income.

The Gini decomposition indicates that the contribution of earnings to total inequality increased slightly over time (from 111.2 to $117.4 \%$ ). It needs to be noted that, inequality contributions tend to be more closely related to factor shares than to factor inequalities or correlations. The other income components that made positive contributions to total inequality were self-employment income, old-age and survivor' benefits and residual categories of market income. Family and children related allowances, residual categories of social transfers and taxes contributed negatively to income inequality and thus acted as income equalizing forces. An inequality-reducing effect caused by family and children related allowances was higher in 2017 than in 2015. With respect to the inequality-reducing effect, income taxes and social insurance contributions were by far the most important factor of income inequality reductions, while the contribution of social benefits was insignificant.

In 2017, there were over 13 million households in Poland, of which one-third (33.8\%) raised dependent children. In the context of the "Family 500+" programme introduction, it is interesting to check how the policy change in 2016, affected the situation of families with children. Whereas the share of family and children related allowances in household income and the inequality-reducing effect caused by this transfer has increased for all households, we want to examine how social protection for families with children affects the reduction of income inequality among them. 
As the starting point for the study, we nominated a group of all households with children, regardless of family composition (Table 2).

Table 2. Gini decomposition by factor components for all households with dependent children

\begin{tabular}{|l|c|c|c|c|c|c|c|c|}
\hline \multirow{2}{*}{ Variable } & \multicolumn{2}{|c|}{$\begin{array}{c}\text { Factor shares } \\
\text { in disposable household } \\
\text { income }\end{array}$} & \multicolumn{2}{|c|}{$\begin{array}{c}\text { Gini } \\
\text { coefficient }\end{array}$} & \multicolumn{2}{|c|}{$\begin{array}{c}\text { Gini } \\
\text { correlation }\end{array}$} & \multicolumn{2}{c|}{$\begin{array}{c}\text { Relative contribution } \\
\text { to overall inequality } \\
(\%)\end{array}$} \\
\cline { 2 - 11 } & 2015 & 2017 & 2015 & 2017 & 2015 & 2017 & 2015 & 2017 \\
\hline Earnings & 93.8 & 89.4 & 0.4439 & 0.4341 & 0.8367 & 0.8342 & 117.5 & 123.1 \\
\hline Selfemp & 15.9 & 14.7 & 0.8381 & 0.8452 & 0.2659 & 0.1928 & 12.0 & 9.1 \\
\hline Othermarinc & 1.9 & 1.4 & 0.9399 & 0.9349 & 0.3785 & 0.3321 & 2.2 & 1.7 \\
\hline Oldsurv & 10.6 & 10.1 & 0.7843 & 0.7693 & 0.0930 & 0.0795 & 2.6 & 2.4 \\
\hline Famchild & 3.5 & 10.4 & 0.8398 & 0.5976 & -0.0472 & -0.1275 & -0.5 & -3.0 \\
\hline Othersocial & 2.8 & 2.2 & 0.8769 & 0.8905 & -0.1983 & -0.2206 & -1.6 & -1.6 \\
\hline Taxes & -28.4 & -28.1 & -0.3873 & -0.3676 & -0.8708 & -0.8035 & -32.3 & -31.6 \\
\hline Total & 100.0 & 100.0 & 0.2964 & 0.2629 & 1.0000 & 1.0000 & 100.0 & 100.0 \\
\hline
\end{tabular}

Source: authors' own calculations.

If we look at the shares of the various income sources in total household income, we can notice that, in 2015 family and children related allowances accounted for $3.5 \%$ of household disposable income. In 2016 the "Family 500+" programme was introduced and this contributed to an increase of the share of cash transfers to families with children to $10.3 \%$. Family and children related allowances were more equally distributed in 2017, and the Gini correlation between this income and total income was stronger $(-0.1275)$, indicating that family and children related allowances favoured the poorer households more than the richer ones. Family and children related allowances contributed negatively to the inequality of household disposable income in all households with dependent children in both years and an inequality-reducing effect caused by this factor was higher in 2017 than in 2015. In conclusion, the increase in cash transfers to families with children was mostly driven by the $500+$ benefit. We can assume that the share of the $500+$ benefit in household income was varied due to number of children in the family. For this reason, we also look at various household types, with particular attention given to households with dependent children consisting of families of different forms.

To better understand the influence of family benefits on income disparities between households with children, the size and type of family should be taken into account. The study covers 5 subgroups of households distinguished based on its composition, i.e., the number of adults and dependent children. The first type of examined household is the group of single persons with dependent children. A number of researchers claim that the rise in income inequality is primarily due to growth in two factors: earnings inequality and the number of households 
with non-traditional family structures, such as single-mother or single-father (Chevan, Stokes, 2000; Martin, 2006). The growth of single-mother (or single-father) families increases income inequality by adding to the population at the bottom of the income distribution.

Table 3. Gini decomposition by factor components for single person with dependent children

\begin{tabular}{|l|c|c|c|c|c|c|c|c|}
\hline \multirow{2}{*}{ Variable } & \multicolumn{2}{|c|}{$\begin{array}{c}\text { Factor shares } \\
\text { in disposable household } \\
\text { income (\%) }\end{array}$} & \multicolumn{2}{|c|}{$\begin{array}{c}\text { Gini } \\
\text { coefficient }\end{array}$} & \multicolumn{2}{c|}{$\begin{array}{c}\text { Gini } \\
\text { correlation }\end{array}$} & $\begin{array}{c}\text { Relative contribution } \\
\text { to overall inequality } \\
(\%)\end{array}$ \\
\cline { 2 - 11 } & 2015 & 2017 & 2015 & 2017 & 2015 & 2017 & 2015 & 2017 \\
\hline Earnings & 80.6 & 70.6 & 0.5594 & 0.5405 & 0.7857 & 0.7269 & 114.6 & 108.6 \\
\hline Selfemp & 10.4 & 8.6 & 0.9377 & 0.9499 & 0.3760 & 0.5220 & 11.9 & 16.7 \\
\hline Othermarinc & 12.6 & 11.5 & 0.6885 & 0.6680 & 0.3428 & 0.4178 & 9.6 & 12.5 \\
\hline Oldsurv & 7.1 & 5.2 & 0.9071 & 0.9136 & 0.1374 & 0.2320 & 2.9 & 4.3 \\
\hline Famchild & 8.7 & 21.3 & 0.7947 & 0.6060 & -0.2630 & -0.1526 & -5.9 & -7.7 \\
\hline Othersocial & 3.8 & 3.4 & 0.8576 & 0.9043 & -0.2380 & -0.3883 & -2.5 & -4.7 \\
\hline Taxes & -23.2 & -20.5 & -0.5208 & -0.5282 & -0.7824 & -0.7021 & -30.6 & -29.7 \\
\hline Total & 100.0 & 100.0 & 0.3092 & 0.2554 & 1.0000 & 1.0000 & 100.0 & 100.0 \\
\hline
\end{tabular}

Source: authors' own calculations.

In 2015, inequality in total disposable income was much higher in single-adult families with children than in all households, however it fell significantly in 2017 (Table 3). The proportion of income from social security in this group was much higher than the relative figure for all households. Family and children related allowances were a major source of income from social transfers in single-adult families with children. The share of this source in disposable income increased during two years from 8.7 to $21.3 \%$, while the relative contribution to total inequality varied between $-5.9 \%$ in 2015 and $-7.7 \%$ in 2017. Family and children related allowances negatively contributed to income inequality in both years. However, the inequality-reducing effect did not increase as spectacularly as the share this factor had in household income.

It needs to be highlighted that in 2017 compared to 2015, the degree to which total income and family and children related allowances were negatively correlated decreased, indicating that in 2017 these benefits favoured poorer households in the smaller extent. It should be added that in 2015 and 2017, the residual categories of market income constituted $12.6 \%$ and $11.5 \%$ of the total disposable income of families of single adults with children, respectively. As already noted, "residual categories of market income" refers to income alimonies for former spouse and children, remittances, gifts in cash etc. The above figures are significantly higher than the average for all households (1.8\% in 2015 and $1.4 \%$ in 2017). 
The other groups of examined households were households of two or more adults with children. These are not necessarily two-parent families. Some of them are one-parent families with adult children as well as minor children. They may also be extended families with children.

First, we analyse households that consist of two adults and one dependent child.

Table 4. Gini decomposition by factor components for two adults with one dependent child

\begin{tabular}{|l|c|c|c|c|c|c|c|c|}
\hline \multirow{2}{*}{ Variable } & \multicolumn{2}{|c|}{$\begin{array}{c}\text { Factor shares } \\
\text { in disposable household } \\
\text { income }\end{array}$} & \multicolumn{2}{|c|}{$\begin{array}{c}\text { Gini } \\
\text { coefficient }\end{array}$} & \multicolumn{2}{c|}{$\begin{array}{c}\text { Gini } \\
\text { correlation }\end{array}$} & $\begin{array}{c}\text { Relative contribution } \\
\text { to overall inequality } \\
(\%)\end{array}$ \\
\cline { 2 - 11 } & 2015 & 2017 & 2015 & 2017 & 2015 & 2017 & 2015 & 2017 \\
\hline Earnings & 108.1 & 108.3 & 0.3776 & 0.3822 & 0.8328 & 0.8531 & 119.6 & 122.6 \\
\hline Selfemp & 14.4 & 14.5 & 0.8863 & 0.8886 & 0.3139 & 0.2023 & 14.1 & 9.1 \\
\hline Othermarinc & 1.8 & 1.4 & 0.9432 & 0.9435 & 0.2857 & 0.4618 & 1.7 & 2.2 \\
\hline Oldsurv & 3.3 & 3.1 & 0.9512 & 0.9483 & 0.0126 & -0.0141 & 0.1 & -0.1 \\
\hline Famchild & 2.2 & 3.9 & 0.9131 & 0.8531 & 0.0969 & 0.0118 & 0.7 & 0.1 \\
\hline Othersocial & 2.0 & 1.9 & 0.9141 & 0.9206 & -0.3795 & -0.3059 & -2.4 & -1.9 \\
\hline Taxes & -31.8 & -33.1 & -0.3520 & -0.3353 & -0.8599 & -0.8306 & -33.8 & -32.0 \\
\hline Total & 100.0 & 100.0 & 0.2843 & 0.2880 & 1.0000 & 1.0000 & 100.0 & 100.0 \\
\hline
\end{tabular}

Source: authors' own calculations.

The Gini coefficient of disposable income of two adults with a dependent child was at a similar level in both years and did not differ from national inequalities. This is also the only group that disposable income inequality slightly increased in 2017 compared to 2015 . The share of family benefits was much smaller in this group of households than in other groups - it accounted for $2.2 \%$ and $3.9 \%$ of household disposable income in 2015 and 2017 respectively (Table 4). It is surprising that family and children related allowances contributed positively to the inequality of household disposable income in both years, but the inequality-increasing effects were insignificant. We state that the government programme "Family 500+" did not have a significant influence on the increase of income in this group because child-raising benefit was granted for every second child under 18 and for the first child if the family income was below PLN 800 per capita per month (PLN 1,200 in the case of child disability).

The second group consisted of households of two adults and two dependent children. Table 5 shows the results of the Gini coefficient decomposition for this group.

In the case of two adults with two children, the Gini coefficient reflects a decline in household income inequality between 2015 and 2017. We also observe a significant decrease in the inequality of family and children related allowances with a simultaneous increase in the share of this source in total income (from 3.2 to $11.5 \%$ ). In 2015, family benefits contributed positively to the inequality of disposable household income, while in 2017 these transfers 
contributed negatively. However, an inequality-reducing effect caused by family and children related allowances was lower in this group than in all households with dependent children.

Table 5. Gini decomposition by factor components for two adults with two dependent children

\begin{tabular}{|l|c|c|c|c|c|c|c|c|}
\hline \multirow{2}{*}{ Variable } & \multicolumn{2}{|c|}{$\begin{array}{c}\text { Factor shares } \\
\text { in disposable household } \\
\text { income (\%) }\end{array}$} & \multicolumn{2}{|c|}{$\begin{array}{c}\text { Gini } \\
\text { coefficient }\end{array}$} & \multicolumn{2}{c|}{$\begin{array}{c}\text { Gini } \\
\text { correlation }\end{array}$} & \multicolumn{2}{c|}{$\begin{array}{c}\text { Relative contribution } \\
\text { to overall inequality } \\
(\%)\end{array}$} \\
\cline { 2 - 11 } & 2015 & 2017 & 2015 & 2017 & 2015 & 2017 & 2015 & 2017 \\
\hline Earnings & 105.1 & 98.5 & 0.4003 & 0.4012 & 0.8739 & 0.8611 & 114.3 & 122.3 \\
\hline Selfemp & 16.7 & 15.6 & 0.8444 & 0.8527 & 0.2997 & 0.2067 & 13.1 & 9.9 \\
\hline Othermarinc & 2.1 & 1.5 & 0.9382 & 0.9345 & 0.5871 & 0.4723 & 3.5 & 2.3 \\
\hline Oldsurv & 0.9 & 0.9 & 0.9817 & 0.9804 & -0.0211 & -0.0352 & -0.1 & -0.1 \\
\hline Famchild & 3.2 & 11.5 & 0.8586 & 0.4107 & 0.1634 & -0.0925 & 1.4 & -1.6 \\
\hline Othersocial & 1.3 & 1.0 & 0.9470 & 0.9389 & -0.3943 & -0.2481 & -1.5 & -0.8 \\
\hline Taxes & -29.2 & -28.9 & -0.3869 & -0.3646 & -0.8771 & -0.8444 & -30.8 & -32.0 \\
\hline Total & 100.0 & 100.0 & 0.3216 & 0.2781 & 1.0000 & 1.0000 & 100.0 & 100.0 \\
\hline
\end{tabular}

Source: authors' own calculations.

The next group of households we studied was "two adults with three or more dependent children". Table 6 shows the results of the Gini coefficient decomposition.

Table 6. Gini decomposition by factor components for two adults with three or more dependent children

\begin{tabular}{|c|c|c|c|c|c|c|c|c|}
\hline \multirow[t]{2}{*}{ Variable } & \multicolumn{2}{|c|}{$\begin{array}{c}\text { Factor shares } \\
\text { in disposable household } \\
\text { income }(\%)\end{array}$} & \multicolumn{2}{|c|}{$\begin{array}{c}\text { Gini } \\
\text { coefficient }\end{array}$} & \multicolumn{2}{|c|}{$\begin{array}{c}\text { Gini } \\
\text { correlation }\end{array}$} & \multicolumn{2}{|c|}{$\begin{array}{l}\text { Relative contribution } \\
\text { to overall inequality } \\
\qquad(\%)\end{array}$} \\
\hline & 2015 & 2017 & 2015 & 2017 & 2015 & 2017 & 2015 & 2017 \\
\hline Earnings & 94.8 & 77.6 & 0.5421 & 0.4969 & 0.8758 & 0.8550 & 122.3 & 122.3 \\
\hline Selfemp & 17.6 & 13.5 & 0.8419 & 0.8479 & 0.2616 & 0.2840 & 10.6 & 12.1 \\
\hline Othermarinc & 3.2 & 1.8 & 0.9239 & 0.9274 & 0.4887 & 0.5366 & 3.9 & 3.4 \\
\hline Oldsurv & 1.4 & 0.8 & 0.9687 & 0.9669 & -0.1248 & -0.1436 & -0.5 & -0.4 \\
\hline Famchild & 8.3 & 26.7 & 0.7023 & 0.3167 & -0.0412 & -0.1022 & -0.7 & -3.2 \\
\hline Othersocial & 2.1 & 1.5 & 0.8615 & 0.9090 & -0.3679 & -0.4770 & -1.8 & -2.5 \\
\hline Taxes & -27.5 & -21.9 & -0.5118 & -0.4773 & -0.8849 & -0.8150 & -33.8 & -31.7 \\
\hline Total & 100.0 & 100.0 & 0.3681 & 0.2694 & 1.0000 & 1.0000 & 100.0 & 100.0 \\
\hline
\end{tabular}

Source: authors' own calculations.

In this group, the biggest decline of inequality was observed in both disposable income and family benefits. In 2015, family and children related allowances accounted for $8.3 \%$ of household disposable income, while in 2017; almost $27 \%$ of their disposable income was attributed to family benefits. The relevant figure for all households with children was found to be $10.4 \%$. It is not a surprise that the households with three or more children had a higher average 
share of family and children related allowances in disposable income than other household groups. One comment that should be made is that an inequality-reducing effect caused by family and children related allowances was higher in 2017 than in 2015.

The last group we studied was "other households with dependent children". These are most often multi-generational families choosing to live together or out of necessity owing to housing affordability, childcare or elderly care.

Table 7. Gini decomposition by factor components for other households with dependent children

\begin{tabular}{|l|c|c|c|c|c|c|c|c|}
\hline \multirow{2}{*}{ Variable } & \multicolumn{2}{|c|}{$\begin{array}{c}\text { Factor shares } \\
\text { in disposable household } \\
\text { income }\end{array}$} & \multicolumn{2}{c|}{$\begin{array}{c}\text { Gini } \\
\text { coefficient }\end{array}$} & \multicolumn{2}{c|}{$\begin{array}{c}\text { Gini } \\
\text { correlation }\end{array}$} & $\begin{array}{c}\text { Relative contribution } \\
\text { to overall inequality } \\
(\%)\end{array}$ \\
\cline { 2 - 11 } & 2015 & 2017 & 2015 & 2017 & 2015 & 2017 & 2015 & 2017 \\
\hline Earnings & 80.2 & 77.9 & 0.4320 & 0.4157 & 0.7967 & 0.8028 & 107.8 & 114.4 \\
\hline Selfemp & 16.3 & 14.8 & 0.7859 & 0.7944 & 0.2013 & 0.1158 & 10.1 & 6.0 \\
\hline Othermarinc & 1.0 & 0.8 & 0.9496 & 0.9387 & 0.3330 & 0.2069 & 1.2 & 0.7 \\
\hline Oldsurv & 21.7 & 20.7 & 0.5768 & 0.5486 & 0.2547 & 0.2379 & 12.5 & 11.9 \\
\hline Famchild & 3.1 & 9.5 & 0.8094 & 0.5812 & -0.1131 & -0.1369 & -1.1 & -3.3 \\
\hline Othersocial & 4.1 & 3.0 & 0.8267 & 0.8457 & -0.0503 & -0.1174 & -0.7 & -1.3 \\
\hline Taxes & -26.4 & -26.7 & -0.3378 & -0.3186 & -0.8530 & -0.7572 & -29.7 & -28.3 \\
\hline Total & 100.0 & 100.0 & 0.2562 & 0.2272 & 1.0000 & 1.0000 & 100.0 & 100.0 \\
\hline
\end{tabular}

Source: authors' own calculations.

The decrease in inequality of disposable income was more moderate in this group than other household groups. Table 7 above shows, more than 3\% in 2015 and $9.5 \%$ in 2017 of disposable income of those households with children was attributed to family benefits when the relevant figure for all households with children was 3.5\% and 10.4\% respectively. Family and children related allowances reduced income inequality in both years and the relative contribution of these transfers to overall inequality was higher in 2017 than in 2015. In this group, significant components of income were old-age and survivor's benefits, which represented the highest proportion of disposable income among the households with children. This was due to the fact that a significant part of this group consists of households with elderly members.

\section{Conclusions}

Previous studies, which analysed the effects of the "Family 500+" programme in Poland most often concerned implications for demography (possible increase in the number of births and the total fertility), impact on the scope and depth of child poverty and implications for 
labour market participation. In this paper we made use of recently available detailed survey data to analyse how different income sources affect the level of inequality in Poland, with focus on the role of family and children related allowances in decreasing income inequalities in 2015 2017. Therefore, we have focused on the various subgroups of households with children.

During the 2015-2017 period, the Gini coefficient reflects a decline in household disposable income inequality in the group of all households. It should, however, be noted that since 2007, in Poland, a gradual decrease in inequality of income before and after social transfers has been observed. This was primarily a result of the reform of the tax-benefit system in 2007 , reforms of the family allowance system, a fall in earnings inequality and positive trends in the labour market. We also have observed a decrease in income inequalities (the Gini coefficient) in the group of all households with children in 2017 compared to 2015 by approximately 11\%. The largest decrease in income inequality took place in the group of households consisting of two adults with three or more children. However, in households of two adults with one child there was a slight increase in income inequality. High levels of income inequality are an obstacle to poverty reduction: poverty and income inequality are part of the same problem. High levels of inequality make it difficult to reduce poverty even when economies are growing (Cook, 2012, p. 69). According to Eurostat, in 2017, after the introduction of the 500+ child benefit, there was a sharp decrease in poverty incidence in the households of two adults with three children and more, and in single-parents' households. At the same time, the poverty rate increased in households of two adults with one child and in households without children.

As expected, due to the "Family 500+" programme, we observe an increase in the share of family and children related allowances in disposable income among households with children. The share of labour income (earnings and income from self-employment) in total household income was negatively associated with the number of members. By contrast, the share of income from family benefits was found to have exactly the opposite trend. This is not surprising, because it results from the assumptions of the "Family 500+" programme which in 2017 was not a universal benefit. It is important to take into consideration the dominant family model in Poland. According to the Polish Central Statistical Office, the majority of Polish families with children consisted of households having one child (more than 53\%). This means that the 500+ child-raising benefit did not cover all households (only low-income families). ${ }^{4}$

\footnotetext{
4 In 2017 , the 500+ child benefit was paid to over 726,000 one-child families, more than 1.5 million families with two children, 306,000 families with three, 56,000 families with four, over 13,000 families with five and 6,000 families with six children, according to the Ministry of Family, Labour and Social Policy.
} 
With respect to the inequality-reducing effect, income taxes and social insurance contributions were by far the most important factor of income inequality reductions in both years. The decomposition results have demonstrated that taxes and contributions decreased income inequality by $32 \%$ on average in the case of all households with children, while family allowances by 0.5 and $3.0 \%$ in 2015 and 2017, respectively. For most households with children, the inequality-reducing effect caused by family and children related allowances increased in 2017 compared to 2015. However, family benefits contributed positively to the inequality of household disposable income in the group of households consisting of two adults with one child in both years. The relative contribution of family and child-related allowances was much higher throughout the period in single-adult families with children than in other groups of households.

From 1 July 2019, the 500+ child-raising benefit was granted also for the first child, regardless of the income of a family. Therefore, our investigations into this area are still ongoing. By making support eligible for every child regardless of income of household, the "Family 500+" programme scheme's extension may also reduce income inequalities among households with one child. Further work needs to be performed to establish whether the impact of family benefits on the level of inequality in disposable income is still positive in this group of households.

\section{Acknowledgment}

This paper is prepared as part of the research project: Income and Inequality of Income of European Households (Eurostat, No.: 162/2018-EU-SILC) and is based on data from Eurostat, EU Statistics on Income and Living Conditions - EU-SILC CROSS-SECTIONAL UDB 2016, 2018 - version 2019-09. The responsibility for all conclusions drawn from the data lies entirely with the authors.

\section{References}

Alves, N. (2012). A view on income redistribution in Portugal and in the European Union. Economic Bulletin and Financial Stability Report Articles and Banco de Portugal Economic Studies. Retrieved from: https:/www.bportugal.pt/sites/default/files/anexos/pdf-boletim/ bol_winter_e.pdf (15.05.2020). 
Brzeziński, M., Najsztub, M. (2017). The Impact of "Family 500+" Programme on Household Incomes, Poverty and Inequality. Polityka Społeczna. Child Benefit Programme 500+ Outcomes and Outputs, 1, ENG (13), 16-25.

Chevan, A., Stokes R. (2000). Growth in Family Income Inequality, 1970-1990: Industrial Restructuring and Demographic Change. Demography, 37, 365-380. DOI: 10.2307/2648048.

Cook, S. (2012). Combating Poverty and Inequality: Structural Change, Social Policy and Politics. In: I. Ortiz, L. Moreira Daniels, S. Engilbertsdóttir (eds.), Child Poverty and Inequality: New Perspectives (pp. 69-78). New York: UNICEF, Division of Policy and Practice.

European Commission (2016). "Family 500+": A new family income-supporting benefit in Poland. ESPN Flash Report 2016/45.

Golinowska, S., Sowa-Kofta, A. (2017). Combating Poverty Through Family Cash Benefits: on the First Results of the Programme "Family 500+" in Poland. Polityka Spoleczna. Child Benefit Programme 500+ Outcomes and Outputs, 1, ENG (13), 7-13.

GUS (2018). Świadczenie wychowawcze, dodatek wychowawczy i dodatek do zryczattowanej kwoty w 2017 r. Warszawa: Główny Urząd Statystyczny.

Hemerijck, A. (2012). When Changing Welfare States and the Eurocrisis Meet. Sociologica, 1, 1-49. DOI: $10.2383 / 36887$.

ILO. (2015). Social protection for children: Key policy trends and statistics. Social Protection Department, International Labour Office. Social protection policy paper No. 14. Geneva.

Kmieć, D. (2019). Professional activity of parents receiving Family 500+ child support in rural and urban areas. Acta Sci. Pol. Oeconomia, 18 (3), 37-45.

Lerman, R.I., Yitzhaki, S. (1985). Income Inequality Effects by Income Source: A New Approach and Applications to the United States. The Review of Economics and Statistics, 67 (1), 151-156. DOI: 10.2307/1928447.

Magda, I., Kiełczewska, A., Brandt, N. (2018). The "Family 500+" child allowance and female labour supply in Poland. OECD Economics Department Working Papers, 1481, OECD Publishing. Paris. DOI: 10.1787/1a30745e-en.

Martin, M.A. (2006). Family structure and income inequality in families with children, 1976 to 2000. Demography, 43, 421-445. DOI: 10.1353/dem.2006.0025.

Myck, M. (2016). Estimating Labour Supply Response to the Introduction of the Family 500+ Programme. CenEA Working Paper Series, WP01/16.

Myck, M., Trzciński, K. (2019). From Partial to Full Universality: The Family 500+ Programme in Poland and its Labor Supply Implications. Ifo DICE report 3/2019, vol. 17.

Nieuwenhuis, R., Van Lancker, W. (2017). Family policies. In: L. Spillman (ed.), Oxford bibliographies in sociology. New York: Oxford University Press. DOI: 10.1093/ OBO/9780199756384-0205. 
Radzik, P. (2017). The Influence of the Government Family 500+ Programme on the Female Labour Force Participation Rate (pp. 57-65). VIII International Scientific Conference Analysis of International Relations. Katowice.

Ruzik-Sierdzińska, A. (2017). Czy program “Rodzina 500+” wywołat efekt na rynku pracy. Warszawa: Instytut Obywatelski.

Saraceno, C. (2011). Family policies, concepts, goals and instruments. Collegio Carlo Alberto, Carlo Alberto Notebooks, 230.

Szarfenberg, R. (2017). Wpływ świadczenia wychowawczego (500+) na ubóstwo na podstawie mikrosymulacji. Polityka Soleczna, 4, 1-6.

UNICEF (2012). Child Poverty and Inequality: New Perspectives. New York: Division of Policy and Practice.

Wodon, Q., Yitzhaki, S. (2002), Inequality and Social Welfare, MPRA Paper No. 12298. Retrieved from: http://mpra.ub.uni-muenchen.de/12298 (24.05.2020).

Yitzhaki, S., Schechtman, E. (2005). The Properties of the Extended Gini Measures of Variability and Inequality. Metron - International Journal of Statistics, LXIII, 401-433. DOI: $10.2139 /$ ssrn.815564.

Yitzhaki, S., Schechtman, E. (2013). The Gini Methodology. A Primer on a Statistical Methodology. Springer. 